\title{
PENGARUH ORANG TUA SEBAGAI BURUH MIGRAN TERHADAP PRESTASI BELAJAR SISWA
}

\author{
Muhammad Musfiatul Wardi \\ Program Studi PGMI, Universitas Muhammadiyah Mataram, Indonesia \\ musfet14@gmail.com
}

\begin{tabular}{l}
\hline \hline INFO ARTIKEL \\
\hline Riwayat Artikel: \\
Diterima: $01-03-2020$ \\
Disetujui: $30-04-20 Q F V C V$ \\
ne netgga 20 \\
\hline
\end{tabular}

\section{Kata Kunci:}

Orang Tua,

Buruh Migrant,

Prestasi Belajar

Keywords:

Parents

Migrant workers,

Learning Achievement

\section{A. LATAR BELAKANG}

Dalam Undang-undang No.20 tahun 2003 tentang sistem pendidikan nasional dirumuskan bahwa pendidikan adalah usaha sadar dan terencana untuk mewujudkan suasana belajar dan proses pembelajaran agar peserta didik secara aktif mengembangkan potensi dirinya untuk memilih kekuatan spritual keagamaan, pengendalian diri, kepribadian, kecerdasan, ahlak mulia, serta keterampilan yang diperlukan dirinya, masyarakat, bangsa, dan negara. ${ }^{1}$ Setiap orang

1 Hermawati, Pendidikan Keluarga Teoritis dan Praktis, (Bandung: PT Remaja Rosdakarya, 2014), 26.

\section{ABSTRAK}

Abstrak: Keluarga adalah wadah pertama dan utama bagi pertumbuhan dan perkembangan swa. Dilingkungan keluarga, orang tua bertanggungjawab untuk membina anak-anaknya dan , Belajar Siswa Anak Buruh Migran Di Madrasah Ibtidaiyah Ma'arif Riyadul Falah Aik Perapa Aikmel Tahun Pelajaran 2017/2018 yang berjumlah 18 peserta didik. Penelitian ini menggunakan pendekatan kuantitatif dengan jenis deskriptif yang menggambarkan secara jelas bahwa, dari perhitungan nilai koefisien penentu (determinan) pengaruh pekerjaan orang tua sebagai buruh migran terhadap prestasi siswa 13\% dan sisanya $87 \%$ ditentukan oleh variabel lain, Berdasarkan hasil perhitungan analisis data ternyata nilai "rxy" adalah 0,746 yang berarti ada pengaruh yang signifikan antara pekerjaan orang tua dengan prestasi belajar siswa. Jika yang dinyatakan bahwa :"terdapat Pengaruh yang signifikan Pekerjaan orang tua sebagai buruh dinyatakan diterima. $\mathrm{m}$

Abstract: Families are the first and foremost container for student growth and development. In the family, parents are responsible for fostering their children and as a defining success especially in education. Economic constraints require that parents leave their children to wander, so that children are being taken into relatives, or in schools so that they are influential in education. This research is a type of quantitative study. This study aims to determine the effect of learning Perapa Aikmel Year lesson 2017/2018, amounting to 18 students. The research uses a quantitative approach with a descriptive type that depicts clarity and systemati. This study used the correlation the determination (determinant) influence of the work of parents as migrant workers against the chement of 13\% students and the remaining 87\% 0.746 is determined by another variable, based on the results of data analysis calculation turns out the value "rxy If viewed from the table coefficient correlation rhitung0,468. Thus the alternative hypothesis (Ha) stated that: "There is a significant influence of the work of the elderly as migrant workers at MI Aikperapa Aikmel East Lombok District Lesson 2017/2018" was declared acceptable. mempunyai hak yang sama dalam mengikuti proses pendidikan. Pendidikan adalah proses wajar yang secara alamiah terjadi dalam kehidupan kita. Tetapi, proses pendidikan yang berlangsung secara alamiah membutuhkan waktu yang sangat lama.

Pendidikan yang berlangsung secara alamiah berarti terjadi secara evolusif, yakni sesuai dengan pola kerja alam. Disebabkan berlangsung lama akan maka didapatkan hasil sebaik-baiknya. Seperti halnya proses evolusi pada berbagai macam spesies makhluk hidup di alam sangat dominan. Oleh karena itulah, tidak ada alasan bagi 
setiap orang untuk sulit mengikuti proses pendidikan. $^{2}$

Keluarga adalah wadah pertama dan utama bagi pertumbuhan dan perkembangan siswa. Jika suasana dalam keluarga itu baik dan menyenangkan, maka siswa akan tumbuh dengan baik pula. Jika tidak, tentu akan terhambatlah pertumbuhan siswa tersebut. Peranan orang tua dalam keluarga amat penting, terutama ibu. Dialah yang mengatur, membuat rumah tangganya menjadi surga bagi anggota keluarga, menjadi mitra sejajar yang saling menyayangi dengan suaminya. ${ }^{3}$ Keluarga jualah tempat dimana seorang siswa mendapat tempaan pertama kali yang kemudian menentukan baik buruk kehidupan setelahnya di masyarakat hingga tak salah lagi kalau keluarga adalah elemen penting dalam menentukan baik-buruknya masyarakat. 4 Di lingkungan keluarga yang berperan sebagai pendidik adalah orang tua dan siswa merupakan amanah bagi para orang tua, oleh karena itu orang tua bertanggungjawab untuk membina siswasiswanya dan mensejahterakan kehidupan mereka. Adapun kesejahteraan kehidupan mereka siswa itu meliputi segi fisik (jasmani) dan mental (rohani). Salah satu bagian dari tanggung jawab pembinaan mental rohani siswa adalah menyekolahkan siswa ke Madrasah atau ke lembaga pendidikan.

Orang tua yang memiliki tingkat pendidikan lebih tinggi memiliki sumber daya yang cenderung lebih besar baik pendapatan, waktu, dan tenaga, yang diberikan untuk meningkatkan prestasi terhadap siswa-siswanya. Tetapi tidak menutup kemungkinan bahwa siswa-siswa yang orang tuanya memiliki tingkat pendidikan rendah, ataupun ditinggalkan sebagai siswa buruh migran, mereka juga mampu untuk menyediakan fasilitas yang layak untuk meningkatkan prestasi siswasiswanya, karena serendah-rendahnya pendidikan orang tua pasti memiliki keinginan yang sangat tinggi darinya. ${ }^{5} \mathrm{Hal}$ ini sesuai dengan pendapat $\mathrm{Ki}$ Hajar Dewantara bahwa seperti apapun keadaan tingkat pendidikan orang tua, pasti menginginkan siswanya lebih tinggi pendidikannya dibandingkan dirinya". 6

\footnotetext{
2 Mohammad Saroni, Pendidikan untuk Orang Miskin, (Jogjakarta: Ar-Ruzz Media, 2013), 188.

3 Zakiah Daradjat, Pendidiksn Islam dalam Keluarga dan Sekolah, (Bandung: CV Ruhama, 1995), 47.

${ }^{4}$ Athiyah Al-abrasy, Dasar-dasar Pokok Pendidikan Islam, (Jakarta: Bulann Bintang, 1993), 133.

${ }^{5}$ Hilman Muchsin. Pengaruh Tingkat Pendidikan Orang Tua Terhadap Prestasi Belajar Anak. Diunduh pada tanggal 30 januari 2018 pukul 23.25 WITA dari: http://hilmanmuchisin.blogspot.com/2012/12/pwngaruh-tingkatpendidikan-orang-tua.html. 2012

${ }^{6}$ Hery Noer Aly \& Munzier S, Watak Pendidikan Islam, (Jakarta: Fisika Agung Insani, 2003), 206.
}

Penelitian yang relevan dengan penelitan ini adalah Peran Ganda Istri TKI dalam Pendidikan Siswa Di Desa Kerumbu Kecamatan Langgudu Kabupaten Bima. Peneliti menyimpulkan bahwa istri para TKI mampu melakukan peran ganda dalam keluarga yaitu selain bekerja di ranah Domistik yaitu mengurus rumah tangga, mereka juga mampu bekerja di ranah publik dengan cara mencari nafkah tambahan berupa berdagang sayur-sayuran, ikan dan ada juga yang bekerja sebagai buruh tani dalam membantu biaya pendidikan siswa-siswanya. Sedangkan penelitian ini mengangkat masalah bagaimana pengaruh orang tua sebagai buruh migran terhadap prestasi belajar siswa.

Peranan ekonomi orang tua secara umum dapat dikatakan mempunyai pengaruh yang positif terhadap peningkatan prestasi belajar siswa. Seperti halnya di Desa Aik Perapa Kecamatan AikMel sebagian besar warganya adalah sebagai buruh migran. Merantau adalah pekerjaan yang sangat diminati oleh sebagian warga sehingga sebagian besar berdampak pada siswa-siswa mereka yang dalam masa perkembangannya yang membutuhkan peran orang tua, siswa yang ditinggal orang tuanya berbeda dengan siswa dibawah didikan orang tua. Seharusnya di rumah siswa-siswa memerlukan, perhatian, motivasi, dukungan, kasih sayang, sarana dan prasarana dari orang tua tetapi, tidak bagi siswa buruh migran.Walaupun di Madrasah sudah banyak usaha guru dalam meningkatkan prestasi belajarnya seperti tambahan jam pelajaran atau Madrasah sore dan ekstrakurikulernya. Namun sebaliknya karena orang tua mereka tidak ada, dan tidak ada yang mengawasi walaupun mereka tinggal dengan keluarga terdekat tetapi mereka kebanyakan disuruh pergi ke ladang dari pada belajar sehingga berdampak pada persoalan seperti malas belajar, masa bodoh dengan belajarnya, dan akibatnya prestasi siswa.

Hasil wawancara dengan kepala madrasah di Madrasah Ibtidaiyah Aik Perapa bahwa siswa buruh migran memang sangat berbeda dengan teman lainnya, mereka kadang murung dan suka berdiam diri, kurang disiplin dan mengganggu temannya. Ada sedikit gangguan kejiwaan karena mungkin tidak mendapatkan kasih sayang dari orang tuanya, bukan hanya siswa buruh migran tetapi banyak orang tua yang cerai ditinggal suami atau istrinya. ${ }^{7}$

Berdasarkan persoalan tersebut peneliti tertarik dengan Pengaruh OrangTua sebagai Buruh Migran Terhadap Prestasi Belajar Siswa Di Madrasah Ibtidaiyah Ma'arif Riyadul Falah Aik 
Perapa Kecamatan Aikmel Tahun ajaran 2017/2018. Dari hasil pemaparan di atas penelitian mengkaji "Bagaimana Pengaruh OrangTua Sebagai Buruh Migran Terhadap Prestasi Belajar Siswa Di Madrasah Ibtidaiyah Ma'arif Riyadul Falah Perapa Aikmel Tahun Ajaran 2017/2018"?

\section{B. METODE PENELITIAN}

Berdasarkan hubungan antar variabel yang diteliti maka jenis penelitian ini adalah menggunakan pendekatan kuantitatif yakni suatu proses yang menemukan pengetahuan yang menggunakan data berupa angka sebagai alat menemukan keterangan mengenai apa yang ingin diketahui. Penelitian ini dapat dikelompokkan sebagai penelitian Deskriptif. Penelitian kuntitatif adalah suatu penelitian dimana data yang diperoleh berbentuk angka-angka. ${ }^{8}$ Penelitian yang digunakan dalam penelitian ini adalah penelitian korelasional yang mencari pengaruh antara dua variabel yang berbeda karena sebab akibat.Jadi penelitian dirancang antara pengaruh orang tua pekerja buruh migran terhadap prestasi belajar siswa.Orang tua sebagai variabel terikat dengan simbol X dan prestasi belajar sebagai variabel bebas dengan simbol Y. Populasi dalam penelitian ini adalah semua siswa anak buruh migran yang ada di Madrasah Ibtidaiyah Ma'arif Riyadul Falah Aik Perapa Aikmel yang berdasarkan hasil wanwancara sebanyak 18 siswa.

\section{Daftar Siswa Anak Buruh Migran}

\begin{tabular}{|c|l|c|l|c|c|}
\hline NO & $\begin{array}{c}\text { Nama Wali } \\
\text { Murid } \\
\text { (Buruh } \\
\text { Migran) }\end{array}$ & $\begin{array}{c}\text { Tempat } \\
\text { Kerja }\end{array}$ & \multicolumn{1}{|c|}{$\begin{array}{c}\text { Nama } \\
\text { Siswa }\end{array}$} & $\begin{array}{c}\text { Kel } \\
\text { as }\end{array}$ & $\begin{array}{c}\text { Jenis } \\
\text { Kelamin }\end{array}$ \\
\hline 1 & Aq. Hafizin & Malaysia & M.Hafizin & V & Laki-laki \\
\hline 2 & Aq. Anto & Malaysia & $\begin{array}{l}\text { Sani } \\
\text { Maulidin }\end{array}$ & V & Laki-laki \\
\hline 3 & Aq. Toni & Malaysia & M. Akbar & III & Laki-laki \\
\hline 4 & Aq. Ayum & Malaysia & Sarbini & III & Laki-laki \\
\hline 5 & Aq. Hamsur & Malaysia & $\begin{array}{l}\text { Huswatun } \\
\text { Nisa }\end{array}$ & VI & Perempuan \\
\hline 6 & Aq. Saprin & Malaysia & $\begin{array}{l}\text { Nurul } \\
\text { Aini }\end{array}$ & VI & Perempuan \\
\hline 7 & Aq.Mujitahidin & Malaysia & Subriadi & V & Laki-laki \\
\hline 8 & Aq. Sabturi & Malaysia & $\begin{array}{l}\text { Lilik K. } \\
\text { Wati }\end{array}$ & III & Perempuan \\
\hline 9 & Aq. Andi & Malaysia & M. Taufik & VI & Laki-laki \\
\hline 10 & Aq. Asrudin & Malaysia & $\begin{array}{l}\text { Ahmad } \\
\text { Zikriadi }\end{array}$ & V & Laki-laki \\
\hline 11 & Aq. Sahdan & Malaysia & Nizam & V & Laki-laki \\
\hline 12 & Aq. Hulpa & Malaysia & Nurhun & V & Perempuan \\
\hline 13 & Aq. Siti & Malaysia & $\begin{array}{l}\text { Raodatul } \\
\text { Jannah }\end{array}$ & V & Perempuan \\
\hline 14 & Aq. Ahmat & Malaysia & $\begin{array}{l}\text { Khaeril } \\
\text { Aldi }\end{array}$ & V & Laki-laki \\
\hline & & & & & \\
\hline 1 & & & & & \\
\hline
\end{tabular}

\begin{tabular}{|c|c|c|c|c|c|}
\hline 15 & Aq. Susanto & Malaysia & Khaeri & VI & Laki-laki \\
\hline 16 & Aq. Irwan & Malaysia & Ulyani & $\mathrm{VI}$ & Perempuan \\
\hline 17 & Aq. Mahaeni & Malaysia & $\begin{array}{l}\text { Nizam } \\
\text { Efendi }\end{array}$ & $\mathrm{V}$ & Laki-laki \\
\hline 18 & Aq. Rudin & Malaysia & Rendi & V & Laki-laki \\
\hline
\end{tabular}

mengumpulkan data tentang variabel terikat yaitu pengaruh orang tua buruh migran (X). Istrumen angket yang akan digunakan dikembangkan oleh peneliti dalam bentuk skala Likert dengan jumlah pertanyaan sebanyak 22 nomor atau item pertanyaan dan tiap-tiap nomor dibagi di dalam beberapa apsen yaitu: apsen A, B dan C dan tiaptiap opsen diberi skor masing-masing yaitu:

1). Jika responden menjawab (ya) diberi skor 3

2). Jika responden menjawab (kadang-kadang) diberi skor 2

3). Jika responden menjawab (tidak) diberi skor 1

Dengan demikian skor bergerak $22 \times 3=66$ (skor maksimum), sedangkan skor minimum $22 \mathrm{x}$ $1=22$. Adapun kisi-kisi angket sebagai berikut:

Kisi-Kisi Instrument Pengaruh Orang Tua Pekerja Buruh Migran

\begin{tabular}{|c|c|c|c|c|}
\hline $\begin{array}{c}\text { Varia } \\
\text { bel }\end{array}$ & $\begin{array}{c}\text { Definisi } \\
\text { Operasional }\end{array}$ & Indikator & Deskriptor & $\begin{array}{c}\text { Butir } \\
\text { item } \\
\text { nomor }\end{array}$ \\
\hline \multirow{12}{*}{$\begin{array}{c}\text { Peng } \\
\text { aruh } \\
\text { oran } \\
\text { gtua } \\
\text { buru } \\
\text { h } \\
\text { migr } \\
\text { an }\end{array}$} & \multirow{12}{*}{$\begin{array}{c}\text { Bantuan } \\
\text { yang } \\
\text { diberikan } \\
\text { orang tua } \\
\text { kepada siswa } \\
\text { dapat belajar } \\
\text { dengan baik. } \\
\text { Meliputi } \\
\text { dukungan } \\
\text { instrumental } \\
\text { (penyediaan } \\
\text { ruang } \\
\text { belajar, } \\
\text { kelengkapan } \\
\text { alat belajar, } \\
\text { pemberian } \\
\text { uang saku), } \\
\text { dukungan } \\
\text { informasiona } \\
\text { l (pemberian } \\
\text { informasi, } \\
\text { pemberian } \\
\text { ide), dan } \\
\text { dukungan } \\
\text { emosional } \\
\text { (simpati, } \\
\text { empati, } \\
\text { perhatian, } \\
\text { dorongan } \\
\text { belajar). }\end{array}$} & \multirow{7}{*}{$\begin{array}{c}\text { Dukungan } \\
\text { instrumental }\end{array}$} & $\begin{array}{c}\text { Persedian } \\
\text { fasilitas } \\
\text { belajar }\end{array}$ & 1,2 \\
\hline & & & $\begin{array}{c}\text { Penyedian } \\
\text { kelengkapan } \\
\text { alat belajar }\end{array}$ & 3,4 \\
\hline & & & $\begin{array}{l}\text { Persediaan } \\
\text { obat-obatan }\end{array}$ & 5 \\
\hline & & & $\begin{array}{l}\text { Pemberian } \\
\text { uang saku }\end{array}$ & 6 \\
\hline & & & $\begin{array}{c}\text { Membantu } \\
\text { menyelesaika } \\
\text { n masalah } \\
\text { belajar }\end{array}$ & 7,8 \\
\hline & & & $\begin{array}{c}\text { Mengatur } \\
\text { waktu belajar } \\
\text { siswa }\end{array}$ & 9,10 \\
\hline & & & $\begin{array}{c}\text { Pemberian } \\
\text { nasehat }\end{array}$ & 11 \\
\hline & & \multirow{2}{*}{$\begin{array}{c}\text { Dukungan } \\
\text { informasiona } \\
1\end{array}$} & $\begin{array}{c}\text { Pemberian } \\
\text { informasi }\end{array}$ & 12 \\
\hline & & & $\begin{array}{c}\text { Pemberian } \\
\text { arahan }\end{array}$ & 13,14 \\
\hline & & $\begin{array}{c}\text { Dukungan } \\
\text { penilaian }\end{array}$ & $\begin{array}{c}\text { Pemberian } \\
\text { penilaian }\end{array}$ & 15 \\
\hline & & \multirow{3}{*}{$\begin{array}{l}\text { Dukungan } \\
\text { emosional }\end{array}$} & $\begin{array}{c}\text { Pemberian } \\
\text { dorongan } \\
\text { belajar }\end{array}$ & 16,17 \\
\hline & & & Perhatian & 18,19 \\
\hline & & & $\begin{array}{c}\text { Simpati dan } \\
\text { empati }\end{array}$ & $\begin{array}{c}20, \\
21,22\end{array}$ \\
\hline \multicolumn{4}{|c|}{ Jumlah } & 22 \\
\hline
\end{tabular}


Untuk dapat data yang lengkap tidak cukup dengan satu metode saja, melainkan dengan beberapa metode yang berkaitan dengan masalahmasalah yang akan diteliti antara lain:Angket, Dokumentasi,Wawancara dan Observasi.

\section{Teknik Analisis Data}

Teknik analisis yang digunakan dalam penelitian ini adalah teknik analisis statistik korelasi product moment untuk menganalisis Pengaruh Orang Tua Sebagai Buruh Migran Tehadap Prestasi Belajar Siswa Di Madrasah Ibtidaiyah Ma'arif Riyadul Falah Aik Perapa AikMel Tahun Pelajaran 2017/2018. Rumus analisis product moment yang digunakan adalah sebagai berikut:

$r x y=\frac{\left[\left(N \sum x y\right)-\left(\sum x \sum y\right)\right]}{\sqrt{\left.\left[\left(N \sum x^{2}\right)-\left(\sum x\right)^{2}\right]\left(N \sum y^{2}\right)-\left(\sum y\right)^{2}\right]}}$

\section{Keterangan:}

$r_{x y}=$ Angka indeks korelasi " $\mathrm{r}$ " product moment

$\sum \mathrm{N}=$ Jumlah sampel

$\sum X=$ Jumlah skor variabel $X$ (pengaruh orang tua)

$\sum \mathrm{Y}=$ Jumlah skor variable $\mathrm{Y}$ (prestasi belajar)

$\sum \mathrm{XY}=$ Jumlah perkalian antara skor $\mathrm{x}$ dan $\mathrm{y}^{9}$

Adapun langkah-langkah yang ditempuh dalam menganalisis data dalam penelitian ini adalah sebagai berikut:

1. Merumuskan hipotesis nol (Ho)

2. Membuat tabel kerja

3. Memasukkan data ke dalam rumus

4. Menghitung nilai korelasi product moment

5. Menarik kesimpulan

\section{HASIL DAN PEMBAHASAN}

Secara umum wilayah Aikperapa merupakan dusun yang berada di Aikmel Utara, merupakan kawasan Taman Nasional Gunung Rinjani (TNGR) bagian selatan.Madrasah ini merupakan wilayah terpencil karena kondisi geografisnya berada di daerah dataran tinggi (pegunungan).Akibat dari geografisnya jauh, pemerintah menggalakkan wilayah ini sebagai lokasi pemberantasan buta aksra, Aikperapa memiliki tingkat buta aksara yang tertinggi dibandingkan dengan wailayah lainnya di Kecamatan Aikmel. Madrasah Ibtidaiyah (MI) Riyadul Falah Aikperapa berdiri pada tahun 2009 dengan nomorpiagam D/Kd.19.03/4/MI/100/ 2011 dan Nomor Statistik Madrasah (NSM) 111252030165. Madrasah ini berdiri dilatorbelakangi oleh Keadaan siswa umur
Madrasah yang makin meningkat di Aikperapa, mengakibatkan Madrasah Dasar Negeri (SDN) yang ada di wilayah tersebut tidak menampung dan perlu didirikan lembaga pendidikan dasar.

Latar belakang pendidikan orang tua siswa yang tidak bisa baca tulis, dan pendidikan mereka rata-rata tidak tamat SD. sehingga masyarakat menaruh harapan besar kepada guru untuk mendidik putra-putrinya. Beberapa kali kasus terjadi, guru mengundurkan diri karena tidak tahan banting menghadapai persoalan-persoalan tersebut ibaratnya seperti seleksi alam. Dengan demikian guru yang mengabdikan dirinya di wilayah ini, harus dilandasi dengan niat cinta dan tulus untuk berjuang membantu masyarakat melakukan perubahana. Bila tidak demikian, seorang guru tidak akan mendapatkan apa-apa.

Siswa MI Riyadul Falah Aikperapa berasal dari pedusunan-pedusunan di Aikperapa, seperti Sempur, Merembuk, dua (2) dusun ini merupakan dusun yang terjauh dari lokasi Madrasah kurang lebih $2 \mathrm{KM}$ jaraknya dari madrasah. Dan beberapa Dusun yang berdekatan dengan Madrasah.Seperti, dusun Pejarakan, Baniara, Pejeruk.

Latar belakang siswa tersebut $90 \%$ adalah berasal dari kalangan kurang mampu secara ekonomi, semua orang tua bermata pencarian sebagai petani dan buruh tani, bahkan yang memprihatinkan $50 \%$ orang tua siswa, menjadi TKI/ TKW Luar negeri (Malaysia). ${ }^{10}$ Mengakibatkan siswa kurang mendapat perhatian/ kasih sayang orang tua mereka, semestinya orang tua merawat mereka saat pendidikan dasar.Namun, karena terdesak kebutuhan ekonomi, memaksa orang tua harus meninggalkan putra-putrinya bekerja ke luar negeri.Karena kalau hanya mengandalkan hasil pertanian di Hutan tidaklah mencukupi untuk kebutuhan, sandang dan papan. Untuk membangun rumah yang layak saja masyarakat Aikperapa harus bertahun-tahun bekerja di Malaysia, apabila ada rumah di Aikperapa yang masih menggunakan pagar, dapat dipastikan bahwa pemiliknya tidak bekerja ke luar negeri. Melihat persoaalan ini, bagi siswa-siswa yang sangat tidak mampu, madrasah melalui yayasan telah memberlakukan program madrasah gratis bagi anak-anak tersebut.Madrasah berperan langsung dalam mencukupi kebutuhan awal pendidikan para siswanya, seperti; baju seragam, baju olahraga, alat-alat tulis menulis, buku penunjang pembelajaran.

Langkah selanjutnya yang harus dilakukan oleh peneliti adalah melakukan uji hipotesis terhadap hasil perhitungan,pengaruh orang tua buruh migran terhadap pretasi belajar Siswa di 
Madrasah Ibtidaiyah Ma'arif Riyadul Falah Aik Perapak Aikmel, apakah hipotesis yang diajukan diterima atau ditolak. Berdasarkan hasil perhitungan analisis data ternyata nilai "rxy" yang diperoleh dari perhitungan $=0,490$. Sedangkan $r$ tabel $=0,468$ yang berarti ada pengaruh yang signifikan antara pekerjaan orang tua terhadap prestasi belajar siswa. Dengan demikian $r_{\text {hitung }}$ lebih besar dari $r_{\text {tabel }}\left(r_{\text {hitung }}>r_{\text {tabel }}\right)$ yaitu $(0,746>0,468$. Dari perhitungan nilai koefisien penentu (determinan) Pengaruh Orangtua sebagai buruh migran terhadap prestasi belajar siswa $13 \%$ dan sisanya $87 \%$ ditentukan oleh variabel lain.

Dengan demikian hipotesis alternatif ( $\mathrm{Ha})$ yang dinyatakan bahwa :"terdapatPengaruh yang signifikan antaraPekerjaan orang tua sebagai buruh migran di MI Aikperapa AikmelKabupaten Lombok Timur Tahun Pelajaran 2017/2018" dinyatakan diterima, Untuk lebih jelasnya dapat dilihat pada tabel hasil analisis data dibawah ini sebagai berikut:

Tabel Hasil Analisis Data Tentang PengaruhPekerjaan orang tua sebagai buruh migran di MI Aikperapa AikmelKabupaten Lombok Timur Tahun Pelajaran 2017/2017.

\begin{tabular}{|c|c|c|c|c|}
\hline & & \multicolumn{2}{|c|}{ Hipotesis } \\
\hline No. & $\begin{array}{c}\text { Nilai } \\
\text { tabel } \\
\text { pada taraf } \\
\text { signifikasi } \\
5 \%\end{array}$ & $\begin{array}{c}\text { Nilai r } \\
\text { hitung }\end{array}$ & Ha & Ho \\
\hline 1. & 0,468 & 0,490 & Diterima & Ditolak \\
\hline
\end{tabular}

Setelah dilakukan penelitian dan diperoleh hasil yang signifikan yaitu terdapat Pengaruh Orangtua sebagai buruh migran di MI Aikperapa Aikmel.Guru, orang tua serta masyarakat dituntut untuk dapat mengarahkan dalam belajar dan menciptakan lingkungan keluarga yang baik untuk dapat mendukung proses belajar mengajar siswa, sehingga dapat tercapai apa yang menjadi tujuan di siswa maupun orang tua itu sendiri. Dengan demikian pengaruh orang tua buruh migran adalah segala sesuatu yang berada di sekitar individu yang merupakan hubungan dan peranan yang sangat penting dalam prestasi belajar siswa.

Orang tua sebagai pendidik dalam lingkungan keluarga sangat dibutuhkan contoh perkembangan dan pertumbuhan seorang siswa.Hal ini jelas karena dalam lingkungan keluarga seorang siswa memperoleh
pendidikan.Sebagai pendidik yang utama dan pertama adalah orang tuanya sendiri. Dengan kata yang lain ibu dan bapaknya, sebagai pendidik harus memperhatikan perkembangan dan pertumbuhan seorang siswa.

Adapaun peranan Madrasah dalam perkembangan siswa didik diharapkan mampu mempersiapkan siswa didik untuk menjadi anggota masyarakat yang berguna bagi agama, bangsa, dan Negara.Dalam hal ini tugas guru yang utama ialah memberikan pengetahuan, sikap dan nilai, dan keterampilan kepada siswa didik. Dengan kata lain, tugas guru yang utama terletak dilapangan pekerjaan.

Peran orang tua sangat penting terhadap prestasi seorang siswa karena dari peranorang tua itu dapat membentuk karakter atau sikapnya masing-masing.Baik itu di lingkungan rumah/keluarga, Madrasah, masyarakat maupun pengaruh orang tua buruh migrandengan teman sebayanya. Jika pendidikan dalam keluargaitu baik maka prestasi seorang siswa cenderung akan baik.Maka sebaliknya jika lingkungan keluarga itu jelek maka prestasi seorang siswa tersebut cenderung menurun. Berdasarkan hasil analisis data, maka variabel (x dan y) terdapat pengaruh, hal ini terbukti dari hasil analisis data yang menunjukkan nilai "rxy" $=0,746$. Sedangkan nilai "rtabel" dari product moment $=0,468$ ini berarti nilai rxy hasil analisis data $=0,746>0,468$ dengan jumlah populasi sebanyak 18 siswa.

Jadi, dari analisis proses penelitian yang dilakukan bahwa hipotesis alternatif diterima karena, nilai pengaruh orang tua buruh migrant lebih rendah dibandingkan dengan nilai prestasi belajar siswa. Sehingga dari perhitungan data yang diperoleh juga membuktikan, terdapat pengaruh orang tua buruh migran terhadap pretasi belajar siswa dari perolehan hasil jawaban angket yang dijawab oleh masing-masing siswa yaitu dari nilai akhir dari nilai r-hitung $=0,746$. Sedangkan pada nilai $r$-tabel $=0,468$. Dengan demikian hasil dari pembahasan tersebut diatas (Ha) diterima.Karena, pengaruh orang tua buruh migran yang kurang mendukung dapat berpengaruh terhadap prestasi belajar siswa.

Dari hasil penelitian yang signifikan, tidak dapat dipungkiri bahwa perbandingan nilai rapor siswa anak buruh migran dengan rapor anak yang orang tuanya bukan buruh migran hampir sama hanya sebagai perbedaan saja bahwa siswa anak buruh migran tidak bisa masuk ke lima besar ataupun tiga besar.

\section{SIMPULAN DAN SARAN}


Berdasarkan pembasan dan analisis data disimpulkan : "Terdapat Pengaruh Orangtua sebagai buruh migran di MI Aikperapa Aikmel Kabupaten Lombok Timur Tahun Pelajaran 2017/2018" yang signifikan. Hal ini dapat dilihat dari hasil analisis data yang menggunakan analisis statistik korelasi product moment dan mendapatkan nilai $r_{\text {hitung }}$ lebih besar dari $r_{\text {tabel }}$ ( $\left.r_{\text {hitung }}>r_{\text {tabel }}\right)$, dimana nilai $r_{\text {hitung }}=0,746$ dan nilai $r_{\text {tabel }}=0,468$ setelah dikonsultasikan dengan nilai $r_{\text {tabel }}$ pada Pengaruh Orangtua sebagai buruh migran terhadap prestasi belajar siswa 13\% dan sisnya $87 \%$ ditentukan oleh varibel lain.

\section{DAFTAR RUJUKAN}

Al-abrasy, Athiyah.Dasar-dasar Pokok Pendidikan Islam. Jakarta. Bulan Bintang, 2010

Arifin, Zaenal. Evaluasi Intruksional Prinsip Teknik Prosedur. Bandung. Rosdakarya, 2016

Arifin.Pokok-pokok Pemikiran Tentang Bimbingan dan Penyuluhan Agama. Jakarta. Bulan Bintang, 2012

Arikunto, Suharsimi, Prosedur Penelitian Suatu Pendekatan Praktik. Yogyakarta. PT Rineka Cipta, 2016

Arikunto, Suharsimi. Prosedur Penelitian suatu Pendekatan Praktik. Jakarta. Rineka Cipta, 2013

Arikunto.Prosedur Penelitian suatu Pendekatan Praktik. Jakarta. PT Rineka Cipta, 2010

Atiah.Hubungan Antar Kecerdasan Spritual dengan Penyesuaian Diri.Proposal. UMM Mataram, 2013

Mappanyompa. Pengaruh Pendidikan Kemuhammadiyahan Terhadap Sikap Perilaku Siswa , 2019, Ibtida'iy Journal PGMI, 4 (1),17-29.

Astuti, Alfira Mulya. Statistika Penelitian. Mataram. Insan Madani Publishing, 2016

Baharudin.Pendidikan \& Psikologi Perkembangan. Jogjakarta. ArRuz Media, 2012

D. Gunarsa. Ny Singgih.Psikologiuntuk Keluarga. Jakarta. Gunung Mulia, 2016

Daradjat, Zakiah. Pendidiksn Islam dalam Keluarga dan Madrasah. Bandung. CV Ruhama, 1995

Darajat Zakiah dkk.Ilmu Pendidikan Islam. Jakarta. PT Bumi Aksara, 2011

Gunawan, Heri. Kurikulum dan Pembelajaran Pendidikan Agama Islam. Bandung.Alfabeta, 2013

Hamdani.Strategi Belajar Mengajar. Bandung. CV Pustaka Setia, 2011
Hermawati.Pendidikan Keluarga Teoritis dan Praktis, (Bandung: PT Remaja Rosdakarya, 2014), 26.

Hery Noer Aly \& Munzier S. Watak.Pendidikan Islam. Jakarta. Fisika Agung Insani, 2003

Ihsan, Fuad. Dasar-Dasar Kependidikan. Jakarta. Rineka Cipta, 2015

Kartono, Kartini. Peranan Keluarga Memandu Siswa, sari Psikologi Terapan. Jakarta. Rajawali Press, 2011

Lestari, Sri. Psikologi Keluarga Penanaman Nilai \& Penanganan Konflik dalam Keluarga. Jakarta. Kencana Prenamedia Group. 2012

Mansur. Pendidikan Siswa Usia Dini dalam Islam. Yogyakarta. Pustaka Pelajar. 2015

Margono.Metode Penelitian Pendidikan. Jakarta. PT Rineka Cipta. 2010

Nawawi.Psikologi Pendidikan. Jakarta. Balai Pustaka, 2013

Purwanto, Ngalim. Psikologi Pendidikan. Bandung. Remaja Rosdakarya, 1915

Sugiyono.Metode Penelitian Pendidikan Pendekatan Kuantitatif, Kualitatif, dan R\&D. Bandung. Alfabeta, 2013

Sugiyono. Metode Penelitian Bisnis, Pendekatan Kuantitatif,Kualitatif dan R\&D. Bandung: Alfabeta, 2010

Mappanyompa. Nilai Pendidikan Islam Dalam Memaknai Khalifah Study Terjemahan Tafsir Al-Misbah Melalui Kajian ,Paedagoria : Jurnal Kajian, Penelitian dan Pengembangan Kependidikan, 2019. 10 (2), 141-146.

Sukmadinta Nana Syaodih.Metode Penelitian Pendidikan. Bandung. PT Remaja Rosdakarya, 2011

Suryabrata Sumadi. Psikologi Pendidikan. Jakarta. Raja Grafindo, 2013

Tirtanegara, Sutraningsih. Siswa Supernormal dan Program Pendidikan. Jakarta. Bina Aaksara, 2014

WS.Winkwl. Psikologi Pendidikan dan Evaluasi. Jakarta. Gramedia, 2010 